\title{
PARKING SERVICES IN THE HOTEL PRODUCT: ADDRESSING THE CHALLENGES OF THE CORONAVIRUS PANDEMIC
}

\author{
Edna Mrnjavac \\ Robert Maršanić \\ Drago Pupavac \\ Ljudevit Krpan
}

https://doi.org//10.20867/tosee.06.35

\begin{abstract}
The purpose of this study is to understand whether and to which extent hotel enterprises, under the impact of the COVID-19 pandemic, have adjusted their business strategies with regard to parking services, given the change in the structure of guests, that is, a decrease in the number of air-travel guests and an increase in the number of car-travel guests. The study examines changes in turnover and guest structure in hotels in central and southern Dalmatia that were focused on air-travel guests in the pre-pandemic period.

The study involved desk research to obtain insight into the responses of hotel enterprises to changed business conditions as a result of the pandemic, with special reference to the modification of business strategies in those segments deemed to be of special importance to individual destinations. This was followed by primary research using the interview method and involving managers in destinations accessible largely by air transport. The aim was to understand the quantitative and qualitative changes in guest turnover caused by the pandemic and to examine the attitude and resulting responses of managers in the segment of parking services for hotel guests. The study reveals the drop and change in the structure of hotel guest turnover and presents the various responses of managers, which ranged from implementing no measures to ensure the required parking spaces, to developing elaborate models.

The contribution of the study is that it identifies the different strategic approaches that can be taken to ensure parking services for hotel guests, as those services are a crucial determinant of the quality of a hotel offering. The modified strategies of hotels in the segment of parking services for guests can serve as a platform upon which individual hotels, based on their specific features, could build their own business models, for the purpose of maintaining a certain turnover of guests until the time the situation in the market returns to normal.
\end{abstract}

Keywords: parking service, hotel, COVID-19, modified strategy.

\section{INTRODUCTION}

The coronavirus pandemic has brought about a worldwide crisis in the tourism industry, including in Croatia. Especially hit are destinations dependent on tourists travelling by air. The long-standing focus of the Croatian tourism industry on guests travelling by car, has resulted in higher tourist traffic relative to other competitive Mediterranean countries in pandemic 2020 year. (https://mint.gov.hr/UserDocsImages/AAA_2020_MINTIS/ dokumenti/200911_sezona_press.pdf) 
ToSEE - Tourism in Southern and Eastern Europe, Vol. 6, pp. 517-531, 2021.

E. Mrnjavac, R. Maršanić, D. Pupavac, Lj. Krpan: PARKING SERVICES IN THE HOTEL PRODUCT ...

Hotel enterprises, along with airlines and travel agencies, have been hit the hardest by the pandemic, and will find it difficult to survive without government support. Hotel managements are faced with huge challenges: from ensuring the required structure and number of employees, across overcoming difficulties in regular supply due to breaks in supply chains, as well as uncertainties in financial flows and business performance, to adjusting the hotel offering to demand. (Breier et al. 2021,7-9).

The above applies in particular to hotel enterprises catering to guests travelling by air. The destination offering targeting these guests is also called into question as local travel agencies encounter problems in their business operations. When the uncertainty of tourism demand trends, as a result of the epidemiological situation, is added to the disappearance of many sales and promotion chains, it is difficult to find solid grounds on which to build a hotel offering (Canhoto and Wei 2020, 2-3).

Given the long-standing and prevailing role of automobiles in tourist arrivals in Croatia, the lack of parking capacities is a major issue in many tourist destinations (Maršanić 2008, 127-144). The lack of parking capacities and parking services affects hotel performance to such an extent that guest satisfaction with the overall hotel offering is decreased (Maršanić and Mrnjavac 2015,392). A secured parking space is a precondition to a hotel guest's unhindered movement in the destination and its environs and to enjoying the destination's tourist attractions. Hotel parking service is an integral element of a destination's traffic solution, which ultimately has a great effect on tourists' satisfaction with their stay in a destination (Pupavac, Maršanić and Krpan 2013, 6).

\section{THEORETICAL BACKGROUND}

\subsection{Literature Review}

The objective of a hotel enterprise is to create a hotel product, which the target market will perceive as a homogenous whole whose value exceeds that of the competition (Mrnjavac and Maršanić 2018, 20). A hotel product is a specific mix on intangible and tangible elements (Mrnjavac and Pavia 2018, 3), in which prevail services focused on communication with users. For a hotel enterprise to develop such a product for demand, which is subject to dynamic and often unpredictable change, it must put in place complex promotion and marketing network structures as well as supply chains to ensure resources required for the production process (Mrnjavac, Pavia and Stipanovic 2011, 14). The activities of stakeholders in the networks provide added value, which does not necessarily need to be of a financial nature (Porter 2014, 16, 66), the exchange of information in continuously monitoring and improving strategic concepts, which can be decisive in ensuring a quick response to unexpected change in business conditions in the environment, such as the COVID-19 pandemic.

Concerning tourism in Croatia, traffic in destinations has been the cause of strong dissatisfaction among guests for many years. Out of 30 elements of a destination's tourism offering, visitors are the least satisfied or strongly dissatisfied with traffic in the destination. They are also very dissatisfied with conditions for people with special needs, (public) local transport, bicycle routes and trails, free Internet traffic, and noise generated 
ToSEE - Tourism in Southern and Eastern Europe, Vol. 6, pp. 517-531, 2021.

E. Mrnjavac, R. Maršanić, D. Pupavac, Lj. Krpan: PARKING SERVICES IN THE HOTEL PRODUCT ...

primarily by traffic. This is the outcome of traffic organisation in destinations, in which $70 \%$ of guests use their own or rented cars for mobility, while only $27 \%$ use some form of public transport (Tomas 2019, 41).

In a complex hotel product, traffic considerations are reflected in the offering of parking space to hotel guests and the accessibility of the hotel facility depending on the organisation of traffic at the local level (Mrnjavac and Slavić 2018, 135). Both of these aspects of traffic still receive far too little attention, however, as witnessed by the small number of studies on this topic.

That this should be so, is difficult to understand considering that as early as the beginning of the last century the need was recognised for scientific research on the interdependence of automobile traffic and the growing need for parking spaces. The first hotel garages, dating back to 1913 and 1914 in the U.S.A., were separate buildings alongside hotels open for business year-round, and had a capacity exceeding 200 cars. Even then hotels were aware of the need for a shuttle service from the garage to the hotel, train station or other locations of interest to guests (McDonald 2007 65, 75-77).

Given the dominant role of the car, hotel guests expect secured parking spaces (Maršanić and Mrnjavac 2018, 392). Studies conducted in coastal destinations in Croatia indicate that a vital determinant of tourist satisfaction is a secured parking space, while the price, type of parking space, distance to hotel, and manner of parking are of secondary importance. (Maršanić and Mrnjavac, 2015, 387-397; Mrnjavac, Pavia and Maršanić $2018,722-732$

Given the growing concerns that the pandemic and its outcomes will not be over anytime soon, Croatia should seek to valorise its position as a car-travel destination on the tourism market. As times of crisis always provide the potential for new advancements, in Croatian tourist destinations this could mark the beginning of the process of transforming the traffic system towards alternative-fuel vehicles. At the local level, an offering should be developed of all forms of alternative mobility, including walking, which would obviously require adjustments to the infrastructure (Slavić, Mrnjavac and Paušić 2020, 254-256).

The pandemic is also a time of new opportunities for hotel enterprises. The differences in strategies will depend upon available resources and pre-defined business objectives. Emphasis should be placed on ensuring the involvement of all stakeholders: employees, guests, suppliers, local administration, the government, and other stakeholders at the national and international levels (Dung 2021, 2). Important factors will be, also, the size of a hotel (the larger the hotel, the more "resistant" to the pandemic), whether it operates year-round or not, and how it cooperates with the destination management company, tour operators, and travel agencies. Being digital channel-oriented will make it possible to avoid direct contact, underlining the hotel's primary focus, which is concern for the health of the hotel guest. Experience up to date has shown that focusing tourism supply on the domestic market has produced good results, due to stakeholders being well informed and there being no special administrative formalities or obstacles for travelling to a destination. 
ToSEE - Tourism in Southern and Eastern Europe, Vol. 6, pp. 517-531, 2021.

E. Mrnjavac, R. Maršanić, D. Pupavac, Lj. Krpan: PARKING SERVICES IN THE HOTEL PRODUCT ...

The newly-defined strategy does not necessarily have to be a long-term business solution. Namely, the information based on which decisions are made is incomplete, subject to change, and probably partially or entirely wrong. The basic business strategy does not necessarily need to be changed completely. A quick check may be limited to individual organisational and business elements, resulting in decisions to revise one or more segments of business operations (Breier et al. 2021, 6). For hotels catering to airtravel guests, this could simply mean turning their focus to car-travel guests. Consequently, it would be necessary to modify the traffic model to ensure sufficient parking capacity for the cars of the hotel's guests.

Figure 1: Interdependence of basic elements in a modified hotel strategy, under the impact of the coronavirus pandemic

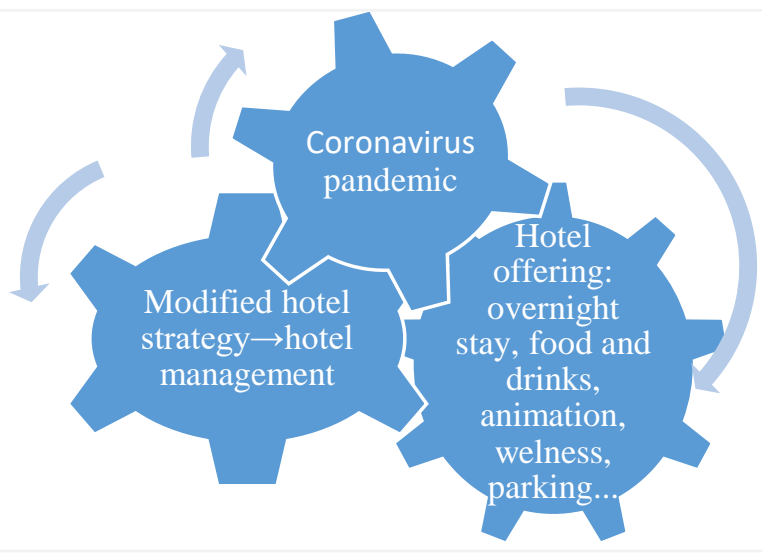

Source: Authors' own construction

The dynamic development of the COVID-19 pandemic and the need for a quick response from managers implies quick decision making. In addition to having the right information, it is also very important to have good cooperation with stakeholders and commitment to a common goal - overcoming the adverse effects of the pandemic. This is a process consisting of three steps: analysing the situation, identifying the necessary changes, and taking concrete measures in agreement with stakeholders (Canhoto and Wei $2021,3)$. Although these steps can be defined more closely, they always come down to the same process in which a hotel's management needs to define, organise and manage a situation (Rastegar, Desbiolles and Ruhanen 2021, 2).

Given the constant change in a hotel's environment, managers need to ensure conditions for good communication with guests and employees. This implies elasticity and adjustment, abandoning earlier models of hotel service in which direct communication was not foreseen or was possible only exceptionally (Jacobs and Chase 2018, 226-227).

In this context, adjusting the offering to changes in the structure of hotel guests to create conditions to receive larger numbers of car-travel guests can be an important strategic response that will enable a hotel to operate and survive in the pandemic and postpandemic period. Considering the ecological impact of a large number of cars in a 
ToSEE - Tourism in Southern and Eastern Europe, Vol. 6, pp. 517-531, 2021.

E. Mrnjavac, R. Maršanić, D. Pupavac, Lj. Krpan: PARKING SERVICES IN THE HOTEL PRODUCT ...

destination and the general trends of sustainable mobility in the EU, however, such a business orientation should not be permanent. Regarding the organisation of traffic in the destination in these conditions, stakeholder cooperation at the local level will be of great importance.

\subsection{Research Concept}

The quality of parking services for hotel guests is affected by the location of the hotel facility, the category of the facility, year-round or seasonal operations, guest structure (length of stay, purchasing power, age, education, special interests, motivations for staying at the hotel and in the destination, the state of parking services in the destination, etc.), and the hotel's strategy and business policy (Mrnjavac and Pavia 2018, 729).

The studies also suggest that if a hotel does not have enough parking spaces available, it is vital that it informs its guests accordingly (Mrnjavac and Pavia 2018, 6). In addition to posting the information on its website, a hotel is recommended, when in direct contact with guests, to call their attention to the fact that it is not able to provide parking services. The hotel should also provide detailed information on the terms of parking in the closest public parking garage or car park.

When a hotel facility does not have enough parking spaces, cooperation with the local authorities is shown to be crucial in finding an adequate solution, which typically comes down to renting, a certain number of parking spaces in a public car park or parking garage. For hotels located in town centres, the regulation of urban traffic in general and public urban transport in particular is especially important.

Basically, guests always appreciate innovation in business operations (Breier et al. 2021, 2 ) because in innovation they see a commitment to providing an improved offering. The motivations of guests, together with their perception of offering quality, have changed significantly due to the pandemic, placing safety and epidemiological standards in the foreground. Changes in guests' level of satisfaction with parking services continue to depend on the availability of vacant parking spaces during their stay at a hotel.

Figure 2 presents the conceptual model of a hotel's strategy in the segment of parking service, modified under the impact of COVID-19. Two groups of factors are identified: 1) factors that, under the influence of the pandemic, are strong driving forces of change, and 2) factors that help mitigate negative effects (Breier et al. 2021, 8). The model includes factors that drive changes to the strategy: diminished market demand for hotel products, reduced income to the level of business losses, altered market structure of guests (drop in share of air-travel guests and rise in share of car-travel guests), mounting pressure on owners to make changes in business operations to abate negative trends, and uncertainty regarding the duration of the pandemic and post-pandemic period. Also included in the model are factors that help to abate negative trends in hotel business operations during the pandemic: cooperation with stakeholders (steady guests, travel agencies and tour operators with access to outbound tourism markets, local authorities, destination management, local tourist boards, public car parks or parking garages, hotels, 
ToSEE - Tourism in Southern and Eastern Europe, Vol. 6, pp. 517-531, 2021.

E. Mrnjavac, R. Maršanić, D. Pupavac, Lj. Krpan: PARKING SERVICES IN THE HOTEL PRODUCT ...

and other stakeholders with a surplus of parking capacities), and the financial support of the state (competent Ministry and Tourist Board).

Figure 2: Conceptual model of hotel strategy in the parking service segment, modified under the impact of COVID-19

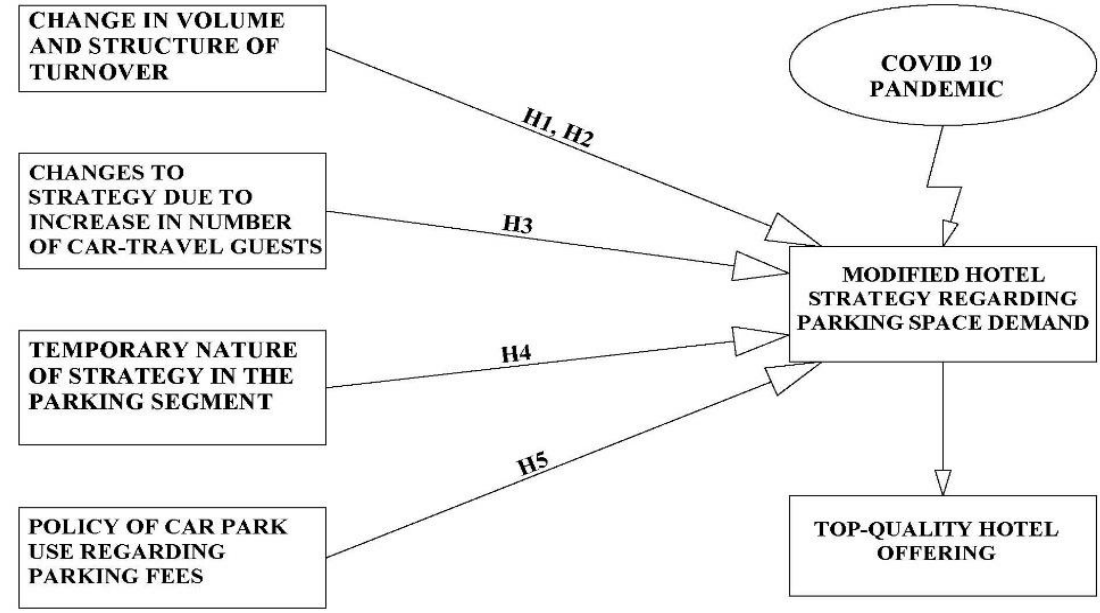

Source: Authors' own construction

Based on the conceptual model, it can be concluded that, under the impact of the COVID19 pandemic, the modification of the hotel operations strategy in the segment of parking service is affected by a drop in the number of guests, the altered structure of hotel guests (fewer air-travel guests, more car-travel guests), the ways of organising car parks to accommodate the increase in number of guests' cars, cooperation with stakeholders in the destination to ensure sufficient parking capacities, and adjusting business policies to the parking service segment (providing information, payment, etc.)

In accordance with the above, the following hypotheses are formulated:

- Hypothesis 1 (H1). The COVID-19 pandemic has influenced a reduction in demand for hotels focused on air-travel guests due to the epidemiological risk related to the transmission of the disease aboard aircraft.

- Hypothesis 2 (H2). Under the impact of the COVID-19 pandemic, hotels focused on air-travel guests have experienced a change in the structure of demand, namely a drop in the number of air-travel guests and a rise in the number of car-travel guests.

- Hypothesis $3(\mathrm{H} 3)$. Hotel enterprises focused on air-travel guests have recognised the potential problem concerning parking service and have developed strategies to accommodate car-travel guests in that segment.

- Hypothesis 4 (H4). The strategies of hotel enterprises to ensure parking capacities are of a temporary nature.

- Hypothesis 5 (H5). To ensure guest satisfaction with the hotel offering, the hotel's business policy does not foresee changes to parking prices. 
ToSEE - Tourism in Southern and Eastern Europe, Vol. 6, pp. 517-531, 2021.

E. Mrnjavac, R. Maršanić, D. Pupavac, Lj. Krpan: PARKING SERVICES IN THE HOTEL PRODUCT ...

\section{MATERIALS AND METHODS}

Primary research was based on a survey of managers of hotels focused on air-travel guests. The survey, conducted from 1 April to 10 May 2021, included hotels in Zadar County, Šibenik-Knin County, Split-Dalmatia County, and Dubrovnik-Neretva County. These counties were selected because, in the pre-pandemic period, air transport accounted for a large share of their tourism traffic, so it was assumed that a change in tourism demand with regard to the choice of transport mode would bring about change in the hotels' business strategies.

Of the 150 questionnaires distributed, 22 were returned, making a response rate of $14.67 \%$. This low response rate results from the fact that a large number of hotels are still closed for business because of the adverse epidemiological situation. A part of the managers apologised for being unwilling to participate in interviews due to the exceptionally difficult business situation caused by the pandemic. Most of the interviews $(91 \%)$ were conducted with managers in Dubrovnik-Neretva County and Split-Dalmatia County, while one interview was conducted with a manager in each of the two remaining counties.

The questionnaire consisted of five general questions and 24 hotel-related questions. The latter were divided into four groups: turnover generated in 2019 (seven questions), parking service for hotel guests (four questions), and turnover generated and parking service in 2020 (13 questions). The first hotel-related group of questions collected general data on the accommodation capacity of the hotel, annual turnover, structure of guests based on means of transportation, seasonality in operations, and other data in 2019, the last year prior to the pandemic years. The second group of questions examined the availability of parking spaces for guests, employees and different types of road vehicles, and the hotel's previous practice when there was a shortage of available parking spaces for guests. The third group of questions focused on turnover in 2020, during the COVID-19 pandemic, relative to the previous year, in particular with regard to any changes in guest structure based on means of transportation. The respondents were also asked about the hotel's standpoint concerning possible shortages of parking capacities, measures taken, basic features of the strategic approach, and cooperation with stakeholders.

Comprehensive insights into a hotel's strategic response relative to parking services and any changes in market structure can be gained by investigating the attitudes of the hotel's management and the attitudes of guests. The limitation of this study to hotel managers was planned, considering that the spread of the pandemic made year-round operations impossible in hotels in the counties that were the focus of the study. The situation caused by the pandemic also made it impossible to investigate hotel guests and parking services in hotels focused on air-travel guests. During the research, another, previously mentioned limitation emerged, resulting in a low response rate, namely hotels, otherwise open, were closed at the time of the interviews and their managers could not be reached.

The sample $(\mathrm{n}=22)$ included $13(59.09 \%)$ business function managers (sales, procurement, etc.) and $9(40.91 \%)$ members of the hotel's management board, of which $13(59.09 \%)$ were male and $9(40.91 \%)$ were female. The educational structure of the sample is favourable: $12(54.54 \%)$ managers have an undergraduate degree; $6(27.27 \%)$, a master's or doctoral degree; 3 (13.63\%), a college degree; and $1(4.5 \%)$, secondary 
ToSEE - Tourism in Southern and Eastern Europe, Vol. 6, pp. 517-531, 2021.

E. Mrnjavac, R. Maršanić, D. Pupavac, Lj. Krpan: PARKING SERVICES IN THE HOTEL PRODUCT ...

school qualifications. The same applies to the age structure, with most managers ( 9 or $40.90 \%$ ) being in the 36-45 age group, and 7 (31.81\%), in the 26-35 age group; 10 hotels $845.45 \%$ ) were from Dubrovnik-Neretva and Split-Dalmatia counties and $1(4.45 \%)$ from Šibenik-Knin and Zadar counties.

Descriptive statistics methodes and Spearman's coefficient of correlation were used in data processing and interpretation. Spearman's coefficient correlation is calculated when one of the data sets is on an ordinal scale, or when data distribution significantly deviates from normal distribution and data are available that considerably diverge from most of those measured (outliers) (3). Linear correlation (Udovičić et al. 2007, 1-138) implied by Pearson's coefficient of correlation, is not required for Spearman's correlation coefficient which can also be calculated for small samples $(\mathrm{N}<35)$. In the case of $\mathrm{r}_{\mathrm{s}}=0$, it may be concluded that there is no actual correlation between variables (1).

\section{RESULTS AND DISCUSSION}

The study included hotels of widely differing capacity. Four hotels $(18.18 \%)$ have a small capacity of 21 to 50 guests; four hotels (18.18\%), a capacity of 101 to 200 guests; and five hotels $(22.72 \%$ ), a capacity of 201 to 400 guests. Two hotels have a very small capacity of up to 20 guests, and two, a very high capacity of 401 to 800 guests. The turnover of guests and the number of overnights in 2019 and 2020 were compared. Guest turnover and the number of overnights in particular show a relatively even distribution: the number of guest arrivals in $14(63.63 \%)$ hotels exceeded 7001 .

Nineteen $(86.36 \%)$ hotels were open for more than 181 days, suggesting large demand and an extended operating season. Prior to the pandemic years, air-travel guests accounted for $71 \%$ or more of guest turnover in nine $(40.91 \%)$ hotels, and for $51 \%-70 \%$ of guest turnover in five $(22.72 \%)$ hotels. The structure of guests based on mode of transportation to the hotel was, to a certain extent, as expected, and the reason why the counties mentioned were included in the study.

The set hypotheses are tested in the following section.

Hypothesis 1 (H1). The COVID-19 pandemic has influenced a reduction in demand for hotels focused on air-travel guests due to the epidemiological risk related to the transmission of the disease aboard aircraft. The study shows that the COVID-19 pandemic caused the hotel business to collapse in the central and southern Dalmatian counties. In 2020, guest turnover and the total number of overnights dropped by $61 \%$ or more in $18(81.81 \%)$ hotels. The number of air-travel guests also dropped by $71 \%$ or more in $18(81.81 \%)$ hotels. The drop in turnover was the greatest in those hotels that focused the most on air-travel guests, prior to the pandemic.

Based on the stated results, Hypothesis 1 is accepted.

Hypothesis 2 (H2). Under the impact of the COVID-19 pandemic, hotels focused on airtravel guests have experienced a change in the structure of demand, namely a drop in the number of air-travel guests and a rise in the number of car-travel guests. As previously pointed out, all hotels that were the subject of the study saw a drop in the number of air- 
ToSEE - Tourism in Southern and Eastern Europe, Vol. 6, pp. 517-531, 2021.

E. Mrnjavac, R. Maršanić, D. Pupavac, Lj. Krpan: PARKING SERVICES IN THE HOTEL PRODUCT ...

travel guests. With regard to the number of car-travel guests, $16(72.72 \%)$ hotels recorded an increase, which helped them salvage what business they could from the tourist season. The increase in number of car-travel guests in hotels relative to the share of air-travel guests in the pre-pandemic period is presented in Table 1.

Table 1: Increase in number of car-travel guests to hotels focused on air-travel guests prior to the pandemic

\begin{tabular}{lcccc}
\hline $\begin{array}{l}\text { Share of air- } \\
\text { travel guests }\end{array}$ & $\begin{array}{c}\text { Increase in number } \\
\text { of car-travel guests }\end{array}$ & $\begin{array}{c}\text { Unchanged number } \\
\text { of car-travel guests }\end{array}$ & $\begin{array}{c}\text { Decrease in number } \\
\text { of car-travel guests }\end{array}$ & Total \\
\hline $71 \%$ and more & 8 & 1 & 0 & 9 \\
$51-70 \%$ & 3 & 0 & 2 & 5 \\
$31-50 \%$ & 4 & 0 & 0 & 4 \\
$11-30 \%$ & 0 & 2 & 0 & 2 \\
Up to $10 \%$ & 1 & 0 & 1 & 2 \\
All Groups & 16 & 3 & 3 & 22 \\
\hline
\end{tabular}

Source: Authors' own construction, based on results obtained by surveying hotel managers

The data in Table 1 demonstrate that hotels with the highest number of air-travel guests prior to the pandemic experienced the greatest increase in the number of car-travel guests during the pandemic. Namely, fully eight of the nine hotels, with the highest prepandemic number of air-travel guests, witnessed an increase in the number of guests arriving by car, which helped to mitigate the negative effect of the pandemic on hotel performance. Notably, only two hotels, in which air-travel guests accounted for more than $50 \%$ of arrivals, experienced a drop in car-travel guest arrivals.

The results of the study confirm Hypothesis 2 .

Hypothesis 3 (H3). Hotel enterprises focused on air-travel guests have recognised the potential problem concerning parking service and have developed strategies to accommodate car-travel guests in that segment. To test Hypothesis 3, correlation analysis was performed for hotel enterprises with a significant share of air-travel guests prior to the pandemic, regarding the number of car-travel guests and the measures taken to resolve parking problems relating to the increased number of guests arriving by car (Table 2).

Table 2: Correlation analysis between share of air-travel guests, number of cartravel guest arrivals, and measures taken

\begin{tabular}{lcccc}
\hline & $\begin{array}{c}\text { Share of air-travel } \\
\text { guests }\end{array}$ & $\begin{array}{c}\text { Car-travel } \\
\text { guest arrivals }\end{array}$ & Measures & $\begin{array}{c}\text { Increase in car- } \\
\text { travel guests }\end{array}$ \\
\hline Share of air-travel guests & 1.000000 & 0.288109 & $\mathbf{0 . 5 1 0 4 0 3}$ & $\mathbf{0 . 5 1 9 2 5 8}$ \\
Car-travel guest arrivals & 0.288109 & 1.000000 & 0.191847 & $\mathbf{0 . 6 6 1 6 3 9}$ \\
Measures & $\mathbf{0 . 5 1 0 4 0 3}$ & 0.191847 & 1.000000 & 0.320398 \\
Increase in car-travel guests & $\mathbf{0 . 5 1 9 2 5 8}$ & $\mathbf{0 . 6 6 1 6 3 9}$ & 0.320398 & 1.000000 \\
\hline
\end{tabular}

Source: Authors' own construction, based on results obtained by surveying hotel managers 
ToSEE - Tourism in Southern and Eastern Europe, Vol. 6, pp. 517-531, 2021.

E. Mrnjavac, R. Maršanić, D. Pupavac, Lj. Krpan: PARKING SERVICES IN THE HOTEL PRODUCT ...

Spearman's coefficient $\mathrm{r}=0.51 ; \mathrm{p}<0.5$ suggests a moderate-good correlation between hotels with a large share of air-travel guests prior to the pandemic and the increase in the number of car-travel guests as well as the measures taken to ensure parking spaces for such guests. Hotel enterprises approached the problem of ensuring parking spaces in one of the ways depicted in Table 3 .

Table 3: Measures taken by hotel enterprises to ensure parking spaces for increased number of guests arriving by car

\begin{tabular}{|c|c|c|c|c|}
\hline & Count & $\begin{array}{l}\text { Cumulative } \\
\text { - Count }\end{array}$ & Percent & $\begin{array}{l}\text { Cumulative } \\
\text { - Percent }\end{array}$ \\
\hline $\begin{array}{l}\text { Usage of a closed hotel car park in the } \\
\text { vicinity }\end{array}$ & 2 & 2 & 9.09 & 9.09 \\
\hline $\begin{array}{l}\text { Repurposed employees' car park for } \\
\text { guests. }\end{array}$ & 5 & 7 & 22.72 & 31.81 \\
\hline No measures taken & 6 & 13 & 27.27 & 59.09 \\
\hline $\begin{array}{l}\text { Repurposed employees' car park for } \\
\text { guests; usage of a closed hotel car park in } \\
\text { the vicinity }\end{array}$ & 1 & 14 & 4.54 & 63.63 \\
\hline $\begin{array}{l}\text { Set up a new car-park space in the } \\
\text { vicinity }\end{array}$ & 3 & 17 & 13.63 & 77.27 \\
\hline $\begin{array}{l}\text { Renting parking spaces in public car } \\
\text { parks }\end{array}$ & 2 & 19 & 9.09 & 86.36 \\
\hline $\begin{array}{l}\text { Repurposed employees' car park for } \\
\text { guests; set up a new car-park space in the } \\
\text { vicinity }\end{array}$ & 2 & 21 & 9.09 & 95.45 \\
\hline Plan to build a hotel garage & 1 & 22 & 4.55 & 100.00 \\
\hline Missing & 0 & 22 & 0.00 & 100.00 \\
\hline
\end{tabular}

Source: Authors' own construction, based on results obtained by surveying hotel managers

A total of 16 hotels took some of the measures, such as repurposing the employees' car park for use by guests. The level of adjustment was minimal, and while it does not suggest any modification to the strategy, it does indicate recognition of the need to address the altered structure of guests. As many as six hotels (27.27\%), however, undertook no measures to adjust to the situation.

Based on the obtained results of the study, hypothesis $\mathrm{H} 3$ is accepted.

Hypothesis 4 (H4). The strategies of hotel enterprises to ensure parking capacities are of a temporary nature. To test the formulated hypothesis, correlation analysis was performed between the increased number of car-travel guest arrivals, the manner in which parking spaces were secured, and the existing plan for the parking of the passenger cars of car-travel guests (Table 4). 
ToSEE - Tourism in Southern and Eastern Europe, Vol. 6, pp. 517-531, 2021.

E. Mrnjavac, R. Maršanić, D. Pupavac, Lj. Krpan: PARKING SERVICES IN THE HOTEL PRODUCT ...

Table 4: Correlation analysis between the number of car-travel guest arrivals, manner in which parking spaces were secured, and the existing plans to ensure more parking spaces

\begin{tabular}{lcccc}
\hline & $\begin{array}{c}\text { Car-travel guest } \\
\text { arrivals }\end{array}$ & $\begin{array}{c}\text { Increase in number } \\
\text { of car-travel guests }\end{array}$ & Mode of parking & Plan \\
\hline Car-travel guest arrivals & 1.000000 & $\mathbf{0 . 6 6 1 6 3 9}$ & 0.258963 & 0.185701 \\
$\begin{array}{l}\text { Increase in number of } \\
\text { car-travel guests }\end{array}$ & $\mathbf{0 . 6 6 1 6 3 9}$ & 1.000000 & 0.149285 & 0.261073 \\
Mode of parking & 0.258963 & 0.149285 & 1.000000 & 0.294107 \\
Plan & 0.185701 & 0.261073 & 0.294107 & 1.000000 \\
\hline
\end{tabular}

Source: Authors' own construction, based on results obtained by surveying hotel managers

Based on the calculation of Spearman's correlation coefficient, it can be concluded that there is no correlation. In other words, the strategies of hotel enterprises to secure parking capacities are of a temporary nature, thus confirming the set hypothesis.

This is also confirmed by the data in Tables 5 and 6 .

Table 5: Manner of ensuring parking spaces for hotel guests, given the increase in number of car-travel guests

\begin{tabular}{lcccc}
\hline & Count & $\begin{array}{c}\text { Cumulative } \\
\text { - Count }\end{array}$ & Percent & $\begin{array}{c}\text { Cumulative } \\
\text { - Percent }\end{array}$ \\
\hline $\begin{array}{l}\text { Spare parking spaces for guests, were } \\
\text { re-activated }\end{array}$ & 10 & 10 & 45.45 & 45.45 \\
Guests advised to use public car park & 3 & 13 & 13.63 & 59.09 \\
Guests used employees' car park. & 3 & 16 & 13.63 & 72.72 \\
Guests advised to use on-street parking. & 4 & 20 & 18.18 & 90.90 \\
No additional parking space secured & 2 & 22 & 9.09 & 100.00 \\
Missing & 0 & 22 & 0.00 & 100.00 \\
\hline
\end{tabular}

Source: Authors' own construction, based on results obtained by surveying hotel managers

Table 6: Existence of a hotel guest car-parking plan, in case of increase in number of car-travel guests

\begin{tabular}{lcccc}
\hline & Count & $\begin{array}{c}\text { Cumulative } \\
\text { - Count }\end{array}$ & $\begin{array}{r}\text { Percent } \\
\begin{array}{c}\text { Cumulative } \\
\text { - Percent }\end{array}\end{array}$ \\
\hline $\begin{array}{l}\text { Prepared strategy to increase park capacity. } \\
\begin{array}{l}\text { Prepared some solutions if number of car- } \\
\text { travel guests increase }\end{array}\end{array}$ & 4 & 4 & 18.18 & 18.18 \\
No plan & 7 & 15 & 50.00 & 68.18 \\
Missing & 0 & 22 & 31.81 & 100.00 \\
\end{tabular}

Source: Authors' own construction, based on results obtained by surveying hotel managers 
ToSEE - Tourism in Southern and Eastern Europe, Vol. 6, pp. 517-531, 2021.

E. Mrnjavac, R. Maršanić, D. Pupavac, Lj. Krpan: PARKING SERVICES IN THE HOTEL PRODUCT ...

Similar to the results obtained in testing $\mathrm{H} 3$, results in testing $\mathrm{H} 4$ also show that a relatively large number of hotels (7) did not make any serious effort to prepare for the possibility of receiving an increased number of car-travel guests. Most of the measures taken by the other hotels rely on temporary solutions, aimed at responding to changes in the structure of guests, that is, to the increase in the number of guests arriving by car, while obviously waiting for the pandemic to end and for things to go "back to normal".

Hypothesis 5 (H5). To ensure guest satisfaction with the hotel offering, the hotel's business policy does not foresee changes to parking prices. To test the formulated hypothesis, correlation analysis was performed between the share of air-travel guests, the share of car-travel guests, and parking prices (Table 7).

Table 7: Correlation analysis between share of air-travel guests, share of car-travel guests, and parking prices

\begin{tabular}{lccccc}
\hline & $\begin{array}{c}\text { Share of } \\
\text { air-travel } \\
\text { guests }\end{array}$ & $\begin{array}{c}\text { Individual } \\
\text { guests }\end{array}$ & $\begin{array}{c}\text { Increase in } \\
\text { number of car- } \\
\text { travel guests }\end{array}$ & $\begin{array}{c}\text { Car-travel } \\
\text { guest } \\
\text { arrivals }\end{array}$ & $\begin{array}{c}\text { Parking } \\
\text { fee }\end{array}$ \\
\hline Share of air-travel guests & 1.000000 & $\mathbf{0 . 8 0 1 7 0 5}$ & $\mathbf{0 . 5 1 9 2 5 8}$ & 0.288109 & -0.201626 \\
Individual guests & $\mathbf{0 . 8 0 1 7 0 5}$ & 1.000000 & 0.274925 & 0.286193 & -0.033770 \\
Increase in number of car- & $\mathbf{0 . 5 1 9 2 5 8}$ & 0.274925 & 1.000000 & $\mathbf{0 . 6 6 1 6 3 9}$ & -0.129381 \\
travel guests & & & & & \\
Car-travel guest arrivals & 0.288109 & 0.286193 & $\mathbf{0 . 6 6 1 6 3 9}$ & 1.000000 & 0.114208 \\
Parking fee & -0.201626 & -0.033770 & -0.129381 & 0.114208 & 1.000000 \\
\hline
\end{tabular}

Source: Authors' own construction, based on results obtained by surveying hotel managers

The obtained Spearman's coefficients lead to the conclusion that there are no correlations between the observed variables. Accordingly, the hypothesis is accepted. This is also confirmed by the research results presented in Table 8 .

Table 8: Attitude of hotel managers towards parking service payment

\begin{tabular}{lcccc}
\hline & Count & $\begin{array}{c}\text { Cumulative } \\
\text { - Count }\end{array}$ & Percent & $\begin{array}{c}\text { Cumulative } \\
\text { - Percent }\end{array}$ \\
\hline $\begin{array}{l}\text { Guests have not been charged for } \\
\text { parking before }\end{array}$ & 16 & 16 & 72.72 & 72.72 \\
$\begin{array}{l}\text { No change - parking fee is acceptable to } \\
\text { our guests. }\end{array}$ & 5 & 21 & 22.72 & 95.45 \\
Abolished parking fees & 1 & 22 & 4.55 & 100.00 \\
Missing & 0 & 22 & 0.00 & 100.00 \\
\hline
\end{tabular}

Source: Authors' own construction, based on results obtained by surveying hotel managers

The presented results indicate that hotel managers have a very positive attitude, meaning they feel the hotel ought not to change its policy regarding parking fees. Notably, in as many as 16 hotels $(72.72 \%)$ there were no parking fees for hotel guests even prior to the pandemic, and one hotel abolished its parking fees.

To summarize the results of the research it follows that all the hypotheses were accepted. 
ToSEE - Tourism in Southern and Eastern Europe, Vol. 6, pp. 517-531, 2021.

E. Mrnjavac, R. Maršanić, D. Pupavac, Lj. Krpan: PARKING SERVICES IN THE HOTEL PRODUCT ...

\section{CONCLUSION}

The COVID-19 pandemic resulted in a decline in tourism traffic. Most affected by the pandemic are the coastal counties - such as Dubrovnik-Neretva County, Split-Dalmatia County, Zadar County, and Šibenik-Knin County - in which air traffic accounts for a significant share of tourism flows. In 2020 the business operations of hotel enterprises, in the mentioned counties, collapsed - namely, in $82 \%$ of hotels turnover dropped by more than $61 \%$. All the hotels saw a drop in the share of air-travel guests, which plummeted by more than $71 \%$ in as many as 18 hotels (82\%). At the same time, $72.72 \%$ of hotels experienced an increase in the number of car-travel guests, which proved to be a vital factor in their efforts to salvage what they could from the tourist season.

Modified business strategies focus on a variety of different business factors and elements. It is to be expected that, given the altered structure of demand, hotels focused on air-travel guests will change the objectives of their business policies and shift towards car-travel guests, which implies the need to ensure the parking capacities.

For the most part, the hotels were prepared to handle the altered structure of guests, each in its own way. The most common solution was to repurpose the employees' car park for use by hotel guests. Some hotels chose to set up a new car-park space by themselves in their vicinity, while others arranged to use the car park of closed hotels or rent a certain number of parking spaces at public car parks. Some combined several of the mentioned measures. It can be noted that these modified strategies are temporary solutions, in the expectation of things to go "back to normal". Only one hotel reported plans to build its own parking garage. Fully seven hotels did not acknowledge the importance of making adjustments to the altered structure of demand and, so, did not develop any modified strategies. The impression is that the hotels mostly took it upon themselves to adjust their strategies to increased demand for parking space and did not at all cooperate with the local authorities or only to a very limited extent.

It is encouraging that hotel managers maintain their current opinion that the hotel should not charge for parking. Although guests rarely make an issue about paying parking fees, this attitude of managers clearly contributes to the positive attitude of hotel guests concerning the efforts of the hotel's management to maintain the high quality of their offering in profoundly altered circumstances.

Although the research included a small sample of hotels without investigating guests' opinion, it is possible to point out some recommendations: the course of the pandemic and vaccionations so far indicate, that the current situation will last and confirms that hotels have to develop strategies for car-travel guests.

Hotel strategies should use "ad hoc" conversion of free space into parking lots, but this will probably not be enough. Hotel management should insist on cooperation with local authorities in order to make optimal use of existing parking capacities. In the long run, hotels need to build their own parking facilities. Destinations should be very careful when building new parking lots and garages because growth of car traffic brings environmental, safety and congestion problems. Hotel management should cooperate 
ToSEE - Tourism in Southern and Eastern Europe, Vol. 6, pp. 517-531, 2021.

E. Mrnjavac, R. Maršanić, D. Pupavac, Lj. Krpan: PARKING SERVICES IN THE HOTEL PRODUCT ...

with local stakeholders on alternative mobility with maximum involvement of information and communication tools.

The results of this study can serve as guidelines for future research which would involve a larger number of hotels. Clearly, future studies should also include hotel guests whose attitudes and opinions would help to provide more comprehensive insight into the success of hotel enterprises in responding to change brought about by the pandemic.

\section{REFERENCES}

Breier, M., Kallmuenzer, A., Clauss, T., Gast, J., Kraus, S. and Tiberius, V. (2021), „The Role of Business Model Innovation in the Hospitality Industry during the Covid-19 Chrisis", International Journal of Hospitality Management, Vol. 92, 102723. https://doi.org/10.1016/j.ijhm.2020.102723

Canhoto, A.I. and Wei, L. (2021), "Stakeholders of the World, Unite: Hospitality in the Time of Covid-19", International Journal of Hospitality Management, Vol. 95, 102922. https://doi.org/10.1016/j.ijhm.2021.102922

Dung, L. and Giang P. (2021), , Strategic Reasponses of the Hotel Sector to Covid-19: Toward a Refined Pandemic Crises Management Framework“, International Journal of Hospitality Management, Vol. 94, 102808. https://doi.org/10.1016/j.ijhm.2020.102808

Jacobs, R.F. and Chase, B.R. (2018), Upravljanje operacijama i lancem opskrbe [Operations and supply chain management], Mate d.o.o., Zagreb.

Maršanić, R. (2008), Parkiranje u turističkim destinacijama, IQ Plus, Kastav

Maršanić, R. (2008), The importance of parking space quality in tourist destination, $6^{\text {th }}$ International Scientific Conference, Management in the Function of Increasing the Tourism, Faculty of Tourism and Hospitality Management, Opatija.

Maršanić, R. (2019), Organizacija parkiranja u urbanim područjima, Naklada Kvarner i Sveučilište Sjever, Novi Vinodoloski i Koprivnica.

Maršanic, R., Mrnjavac, E., Pupavac, D. and Krpan, L. (2021), Stationary Traffic as a Factor of Tourist Destination Quality and Sustainability, Sustainability, Vol. 13, No. 7, 3965 https://www.mdpi.com/2071-1050/13/7/3965/htm, https://doi.org/10.3390/su13073965

Maršanić, R. and Mrnjavac, E. (2015), ,Role of Parking in the Hotel Supply Chain Management“, Scientific Journal of Logistics, Vol. 11, No. 4, pp. 387-397, https://www.logforum.net/pdf/11_4_7_15.pdf, doi: 10.17270/J.LOG.2015.4.7

Marušić, Z. et al. (2020), Stavovi i potrošnja turista u Hrvatskoj (Tomas 2019), Institut za turizam, Zagreb. http://iztzg.hr/hr/projekti/tomas-istrazivanja/

McDonald, S.S. (2007), The Parking Garage - Design \& Evolution of a Modern Urban Form, Urban Land Institute, Washington.

Mrnjavac, E. and Maršanić, R. (2018), „Parking - An Element of Hotel Product Quality“, in Mrnjavac, E. (Ed.), Supply Chain Management in Hospitality Industry, University of Rijeka, Faculty of Tourism and Hospitality Management, Opatija, pp. 19-32.

Mrnjavac, E. and Pavia, N. (2018), „Influence of Mobility Management on Hotel Offer“, in SHS Web of Conferences, Vol. 57, 012021. https://doi.org/10.1051/shsconf/20185701021

Mrnjavac, E., Pavia, N. and Maršanić, R. (2018), "Parking as an Important Service of Innovative Hotels: a Case of Croatia”, Innovation Management, Entrepreneurship and Sustainability (IMES 2018), pp. 722-733. https://imes.vse.cz/wp-content/uploads/2018/07/Conference Proceedings IMES 2018.pdf

Mrnjavac, E. and Slavić, N. (2018), "Mobilnost građana Republike Hrvatske. Iskustva i stavovi s osvrtom na turizam", Acta turistica, Vol. 30, No. 2, pp. 129-154.

Mrnjavac E., Pavia N. and Stipanović C. (2011), "Logistics Systems in Tourism", Logistic systems in Global Economy, Siberian State Aerospace University, Krasnojarsk, Russia, pp. 10-20.

Porter, M.E. (2014), "Konkurentska prednost - postizanje i održavanje vrhunskog poslovanja" [Competitive Advantage], Masmedia, Zagreb.

Pupavac, D., Maršanić, R. and Krpan Lj. (2013), "Significance of Stationary Traffic as Factor in Logistics Systems in Tourist Destinations", DIEM 2013, Dubrovnik, viewed 21 April 2021 , https://hrcak.srce.hr/161563 
ToSEE - Tourism in Southern and Eastern Europe, Vol. 6, pp. 517-531, 2021.

E. Mrnjavac, R. Maršanić, D. Pupavac, Lj. Krpan: PARKING SERVICES IN THE HOTEL PRODUCT ...

Rastegar, R., Desbiolles, F.H. and Ruhanen,L. (2021) "Covid-19 and a Justice Framework to Guide Tourism Recovery", Annals of Tourism Research, Vol. 89, pp. 1-4 https://doi.org/10.1016/j.annals.2021.103161

Slavić, N., Mrnjavac, E. and Paušić, I. (2020), "Croatian Urban Transportation Systems in 2020: Sustainable Urban Mobility Survey", 20 $0^{\text {th }}$ International Scientific Conference Business Logistics in Modern Management, Osijek, pp. 251-274.

Udovičić, M., Baždarić, K., Bilić-Zulle, L. and Petrovečki, M. (2007), "What we need to know when calculating the coefficient of correlation?", Biochemia Medica, Vol. 17, No. 1, pp. 10-15.

Edna Mrnjavac, PhD, Full Professor

University of Rijeka, Faculty of Tourism and Hospitality Management

Department of Logistics and Tourism Resources

Primorska 46, 51410 Opatija, Croatia

+385-51-294 699

ednam@fthm.hr

Robert Maršanić, $\mathrm{PhD}$

University of North Koprivnica and Road Administration Primorje-Gorski Kotar County

Trg dr. Žarka Dolinara 1, 48000 Koprivnica, Croatia

+385-99-5790183

rmarsanic@unin.hr

Drago Pupavac, Phd

Polytechnic of Rijeka

Trpimirova 5, 51000 Rijeka, Croatia

$+385-98-9071218$

drago.pupavac@ri.t-com.hr

Ljudevit Krpan, PhD, Full Professor

University of North Koprivnica and Administrative Department for Regional Development, Infrastructure and Project Management of Primorje-Gorski Kotar County

Adamićeva 10, 51000 Rijeka, Croatia

+385-99-802 0233

ljudevit.krpan@pgz.hr 